\title{
REMEDY HOLES AND BOTTOMLESS RIGHTS: A CRITIQUE OF THE INTENT- TO-USE SYSTEM OF TRADEMARK REGISTRATION
}

\author{
TRACI L. JONES*
}

The Trademark Law Revision Act ("TLRA") was championed as an innovation in American trademark law ${ }^{1}$ when it was enacted by Congress in $1988 .^{2}$ This law represented not only the "first comprehensive revision of the Lanham Act ${ }^{3}$ since it was adopted in 1946," but also a departure from the Lanham Act's traditional use-based trademark system. ${ }^{5}$ This departure was the result of a new system of trademark registration ${ }^{6}$ based on intent to use a mark rather than on actual use of a mark. ${ }^{7}$

Prior to the passage of the intent-to-use ("ITU") registration provisions, a trademark owner could accrue common law or registration rights only after the mark was actually used in commerce. ${ }^{8}$ Currently, with the ITU option, one can start the registration process by merely claiming an intent to use the mark. ${ }^{9}$ The ITU application process allows applicants to clear the procedural hurdles of registration prior to making a significant monetary investment in a mark. ${ }^{10}$

Copyright $(\mathcal{O} 1996$ by Law and Contemporary Problems

* J.D. Candidate, Duke University School of Law, 1997.

The author would like to thank Jerome Gilson, Jeff Handelman, David Lange, Pete Siwinski, and Laura Underkuffler for their invaluable contributions and Bill and Sylvia Jones for their support.

1. See I JEROME GILSON, TRADEMARK PROTECTION AND PRACTICE \& 1.04[4][B] (1992); see also Henry W. Leeds, Intent To Use-Its Time Has Come, 79 TRADEMARK REP. 269, 269 (1989) (describing the parameters of the intent-to-use system).

2. Pub. L. 100-667, 102 Stat. 3935 (codified in scattered sections of 15 U.S.C. (1994)).

3. 15 U.S.C. $\$ 1051-1127$ (1994).

4. Robert J. Eck, Statement of the United States Trademark Association in Support of S. 1883 (DeConcini) The Trademark Law Revision Act, 78 TRADEMARK REP. 382, 384 (1988).

5. Id.

6. See 15 U.S.C. $\$ \S 1051-1052,1057$ (1994) (the intent-to-use provisions).

7. The terms "mark" and "trademark" are synonymous. For definitions of the terms, see 15 U.S.C. \$ 1127 (1994).

8. See La Societé Anonyme des Parfums LeGalion v. Jean Patou, Inc., 495 F.2d 1265, 1270 (2d Cir. 1974).

9. 2 J. THOMAS MCCARTHY, TRADEMARKS AND UNFAIR COMPETITION $§ 19.08[1][\mathrm{a}]$ (3d ed. 1995); see also Leeds, supra note 1, at 270-72.

10. United States Trademark Association, Trademark Review Commission, Report and Recommendations to USTA President and Board of Directors, 77 TRADEMARK REP. 375, $392-93$ (1987) [hereinafter TRC Report]. 
However, even under this system, rights in the mark do not vest until the mark is actually used and registered. ${ }^{11}$

Because rights are conferred after the application process begins, the terms "applicant" and "registrant" label individuals in two very different periods in the ITU system. One is an "applicant" prior to using the mark when he is fulfilling the procedural requirements for registration, and one is a "registrant" after he uses and registers the mark. After one becomes a registrant, the full rights of the trademark are realized. ${ }^{12}$

Congress adopted these provisions to accomplish very specific goals. First, the legislature wanted to increase the certainty of registration through the ITU provisions. ${ }^{13}$ Prior to the passage of these provisions, businesses incurred production and marketing costs associated with a trademark without any guarantee that the mark would be registerable. ${ }^{14}$ The legislature realized that this scheme was "logistically perverse." 15 Further, the new provisions made token use of marks unnecessary. ${ }^{16}$ The traditional registration requirement caused some businesses to contrive use of a mark by making mock shipments or sales across state lines. ${ }^{17}$ Finally, the ITU system diminished the disparity between foreign and domestic filing requirements. ${ }^{18}$ Foreign applicants had been allowed to register marks under section 44 of the Lanham Act, ${ }^{19}$ which did not require the foreign applicant to use his mark in U.S. commerce prior to registration. ${ }^{20}$ The lack of a domestic use requirement for foreign filers was perceived by some members of Congress to be an unfair foreign advantage. ${ }^{21}$

Nearly eight years after the passage of the TLRA, there is some question whether the ITU provisions have realized any of these goals. ${ }^{22}$ Although judicial decisions have sought to clarify the provisions, these decisions have created awkwardness and tension within the system. ${ }^{23}$ There are two particular-

11. Id. at 403 .

12. See infra Part II.

13. Trademark Law Revision Act of 1988, S. Rep. No. 100-515, at 5-6 (1988) [hereinafter S. Rep. No. 100-515], reprinted in UNITED STATES TRADEMARK ASSOCIATION, THE LEGISLATIVE HISTORY, REPORTS, TESTIMONY, AND ANNOTATED STATUTORY TEXT OF THE TRADEMARK LAW REVISION ACT OF 1988, at 157-58 (1989) [hereinafter TLRA HISTORY].

14. Frank Z. Hellwig, The Trademark Law Revision Act of 1988: The 100th Congress Leaves Its Mark, 79 TRADEMARK REP. 287, 291-92 (1989).

15. Id.

16. S. REP. No. 100-515, supra note 13, at 6, reprinted in TLRA HISTORY, supra note 13, at 158.

17. USTA Testimony before the Subcommittee on Courts, Civil Liberties and the Administration of Justice of the House Judiciary Committee, 100th Cong. (1988), reprinted in TLRA HISTORY, supra note 13 , at $227,229$.

18. Statement of Rep. Carlos J. Moorhead, reprinted in TLRA HISTORY, supra note 13, at 129-30. Rep. Moorhead introduced the TLRA by underscoring the need to "put[] American and foreign businesses on essentially the same footing when they apply to register trademarks in the United States." Id.

19. 15 U.S.C. \& 1126(a)-(i) (1994).

20. S. REP. No. 100-515, supra note 13, at 5, reprinted in TLRA HISTORY, supra note 13, at 157.

21. Id. Approximately $7 \%$ of the Patent and Trademark Office's active trademark applications and registrations claim the benefit of non-use through $\S 44$. Id.

22. See, e.g., 2 MCCARTHY, supra note $9, \$ 19.08[1][d]$, at $19-56$ to -61 .

23. See id. $\$ 19.08[1][\mathrm{a}]$, at $19-52$ to -54 . 
ly awkward aspects of the system. First, applicants have no judicially enforceable rights in their marks. Until a mark is actually registered, the applicant can do nothing to protect his interests. Second, once rights are granted, the registrant may have too broad a legal right vis-à-vis common law owners of a similar mark. The exceptions to an ITU registrant's rights to a mark are so ambiguously worded that the registrant may be able to usurp the valid rights of other mark users. These two aspects of the ITU system have opposite, but equally troubling effects. The former tends to diminish the legal rights of applicants, creating a remedy hole. The latter tends to expand the benefits of registration too far, giving registrants bottomless rights. The resultant awkwardness within the system seriously weakens it. ${ }^{24}$

The purpose of this article is to identify the causes of tensions within the ITU system, to explore these causes in light of the system's legislative history, and to evaluate methods of eliminating these tensions. Part II briefly outlines the basics of trademark law, lays out the ITU application system, explains its constructive use provisions, and identifies the expected benefits of the ITU scheme. Part III addresses the first problem of the ITU system, the extent of an applicant's enforceable rights. It examines why applicants are afforded no legal protection and the consequences of this absence, and offers an alternative method of protecting applicants. Part IV explores a potential hot spot in the system, the prior use exception to a registrant's nationwide priority. Because this exception has received little judicial attention, its vagueness necessitates an attempt to clarify its meaning.

\section{II}

\section{THE TRADEMARK REgISTRATION SYSTEM}

\section{A. The Nuts and Bolts of Trademark Law and Intent-to-Use Provisions}

Trademarks are words, names, symbols, or devices, or any combination thereof, adopted and used by a manufacturer or merchant to identify his goods. $^{25}$ The true function of these marks is to distinguish goods for consumers. ${ }^{26}$ Goods bearing a particular mark are generally of uniform quality. Thus, consumers can observe the mark, use it as a symbol of quality, ${ }^{27}$ and select specific "brands" while avoiding others. ${ }^{28}$

24. See, e.g., infra notes 140-47 and accompanying text (arguing that ITU plaintiffs cannot vindicate their rights); infra notes 153-73 (arguing that ITU plaintiffs are systematically undercompensated).

25. 15 U.S.C. \$ 1127 (1994).

26. 1 GILSON, supra note $1, \S 1.03[5][a]$, at $1-30$ to -31 .

27. See Mishawaka Rubber \& Woolen Mfg. Co. v. S.S. Kresge Co., 316 U.S. 203, 205 (1942); Louisiana-Pacific Corp. v. Nu-Sash of Pittsburgh, Inc., 184 U.S.P.Q. 593 (W.D. Pa. 1974).

28. 1 GILSON, supra note $1, \S 1.03[5]$ [b], at 1-31. Mr. Gilson illustrates well this point; he compares buying a television without trademarks to buying a ZENITH, SONY, or RCA. If a consumer can distinguish between the televisions by observing different marks, his purchasing choice is simplified. Id. 
This impact of trademarks on consumers is the crux of trademark law. ${ }^{29}$ Legal rights to a trademark merely reflect "the law's recognition of the psychological function of symbols. If it is true that we live by symbols, it is no less true that we purchase goods by them." ${ }^{\prime 30}$ Courts protect trademark rights by preserving the "brand name" quality, or goodwill, that the mark symbolizes. ${ }^{31}$ Without this protection, third parties could copy the mark and trade on its owner's goodwill. ${ }^{32}$ The copy-cat products could then cause the mark to symbolize poor quality, and the owner's investment in the mark could be destroyed. ${ }^{33}$

Legal rights in a mark can stem from either a common law or statutory basis. Through the application of common law, an individual can obtain rights in a mark without actually registering it: ${ }^{34}$ The first user of a mark has a right to use the trademark that takes precedence over all other potential users, at least in the locale ${ }^{35}$ where the mark was first used. ${ }^{36}$ Under the Lanham Act, the federal trademark law, ${ }^{37}$ an individual can obtain statutory rights in a trademark through registration. ${ }^{38}$ Prior to the TLRA, the individual had to actually use the trademark in commerce in order to register it. ${ }^{39}$ Thus, "federal registration ... d [id] not alter the basic common law requirement of use. $"{ }^{\prime 40}$ Under either framework, use of a trademark was the harbinger of trademark

29. Mishawaka, 316 U.S. at 205. The aim of trademark use is "to convey through the mark, in the minds of potential customers, the desirability of the commodity upon which it appears. Once this is attained, the trade-mark owner has something of value." Id.

30. Id. (noting that a trademark is a merchandising short-cut that induces a purchaser to select what he wants or what he has been led to believe he wants).

31. United Drug Co. v. Theodore Rectanus Co., 248 U.S. 90, 97 (1918) (concluding that a mark's "function is simply to designate the goods as the product of a particular trader and to protect his good will against the sale of another's product as his").

32. Mishawaka, 316 U.S. at 205 (noting that the phrase "trading on the owner's goodwill" terms the phenomenon identified by Justice Frankfurter as "poaching upon the commercial magnetism of the symbol [the mark owner] has created").

33. Id.

34. Bruce R. Parker, "Intent to Use": On the Road Toward Adoption of a Registration-Based System of Trademark Protection, 79 TRADEMARK REP. 319, 319 (1989).

35. See Tally-Ho, Inc. v. Coast Community College Dist., 889 F.2d 1018 (11th Cir. 1989); see also 15 U.S.C. \$ $\$ 1067-69$ (1994) (the concurrent use provisions). This potentially limited scope of trademark rights stands in opposition to registration priority rights, which are nationwide in effect. Id. $\S 1114(1)$ (granting a remedy of infringement against " $[a]$ ny person who uses a confusingly similar mark in commerce" (emphasis added)).

36. New West Corp. v. NYM Co. of Cal., Inc., 595 F.2d 1194, 1200 (9th Cir. 1979).

37. La Societé Anonyme des Parfums LeGalion v. Jean Patou, Inc., 495 F.2d 1265, 1270 n.5 (2d Cir. 1974) (stating that when "the Lanham Act is not the source of the right sued upon, state law applies").

38. See 15 U.S.C. \& 1051 (1994).

39. La Societé, 495 F.2d at 1271. "The Lanham Act does not create the trademark right; it only recognizes the right acquired through use." Id. at 1270 n.5.

40. Id. 
rights. ${ }^{41}$ As a result, American ${ }^{42}$ trademark law was characterized as "no trade-no trademark. ${ }^{\prime 43}$

The ITU provisions ${ }^{44}$ of the TLRA authorized a new system of accruing trademark rights that does not require use of the mark in commerce. ${ }^{45}$ Under these new statutory provisions, individuals can apply for trademark registration based on a bona fide intention ${ }^{46}$ to use a mark. ${ }^{47}$ The application process grants the applicant a right to the mark contingent upon registration.

The application requirements of the ITU system are codified in sections 1(b) and (d) of the amended Lanham Act. ${ }^{48}$ Under these provisions, a trademark registrant begins the registration process by submitting to the Patent and Trademark Office ("PTO") a statement of a bona fide intent to use a mark, a drawing of the mark,,$^{50}$ and an ITU application..$^{51}$ Upon receipt, the application is fully examined ${ }^{52}$ by an Examining Attorney. ${ }^{53}$ Barring any unresolved office actions ${ }^{54}$ the application is published in the Official Gazette ${ }^{55}$ After publication and any opposition proceedings, ${ }^{56}$ the applicant is given a notice of

41. Id. ("trademark use is accepted as a general common law requirement, with no discernible modulations from jurisdiction to jurisdiction").

42. Until the passage of the TLRA, only the United States and the Philippines required use of a mark before filing an application for registration. Eck, supra note 4, at 387.

43. TRC Report, supra note 10, at 392.

44. Codified in scattered sections of 15 U.S.C. (1994).

45. 1 GILSON, supra note $1, \S 1.04[4]$, at $1-56$ to -70 .

46. See infra note 49 for a discussion of bona fide intent.

47. See, e.g., 15 U.S.C. $\S 1051$ (b) (1994) (authorizing registration based on a bona fide intent to use); id. $\S 1057$ (c) (defining constructive use based on intent to use).

48. Id. $\S 1051(\mathrm{~b}),(\mathrm{d})$.

49. Specifically an applicant must show a "bona fide intention, under circumstances showing the good faith of such person, to use a trademark in commerce." Id. $\$ 1051(1)(\mathrm{b})$. The level of intent necessary to qualify as bona fide is determined on a case-by-case basis, evaluating all surrounding circumstances. 1 GILSON, supra note $1, \S 3.04[2][\mathrm{c}]$, at 3-90 to -92 . This intent should be measured by objective factors. Id. Generally, the more concrete an applicant's steps have been toward introducing the mark on a product, the more likely that bona fide intent will be found. Id.

50. If the registration were based on use, an actual specimen of the mark's use in commerce would be required.

51. 15 U.S.C. $\S 1051$ (b) (1994).

52. For a discussion of examination procedures of the PTO, see 1 GILSON, supra note $1, \S 3.04[4][$ a], at 3-96 to -98 .

53. See 15 U.S.C. $\$ \S 1052,1062$ (a) (1994) (examination of application and publication of marks entitled to registration).

54. An office action is the Examining Attorney's refusal to publish the mark because, for example, the mark is likely to be confused with another existing mark, or because the mark is descriptive. An applicant is allowed to submit office action responses to the Examining Attorney in an effort to have the mark reexamined and approved. See id. § 1062(b) (examination of application-refusal of registration when not entitled); see also 1 GILSON, supra note $1, \$ 3.04[4][\mathrm{b}]$, at 3-97 to -98 .

55. 15 U.S.C. $\S 1051(d)(1)(1994)$.

56. Publication in the Official Gazette alerts other mark owners of the upcoming registration of a mark. The other owners can then oppose the registration of the published mark if the published and owner's marks are so similar that they are likely to be confused. Id. $\$ 1063$ (opposition to registration of marks on the principal register); see also TRC Report, supra note 10, at 397-98. 
allowance. ${ }^{57}$ This is a green light, which lets the applicant know the mark is registerable and will be registered upon its use. The applicant then has six months either to use the mark in commerce and file a declaration of use, or to file an extension of time to declare use. ${ }^{58}$ An applicant can file several extensions, as long as the total extension period is no more than twenty-four months. ${ }^{59}$ When the declaration of use is filed and accepted by the PTO, the mark is registered on the Principal Register. ${ }^{60}$ At that point, the ITU applicant becomes a registrant and realizes all the rights of a trademark owner.

\section{B. Section 7(c) and Constructive Use Priority}

Under the ITU provisions, registration is a two-step procedure. ${ }^{61}$ The first step requires filing an application based upon a bona fide intent ${ }^{62}$ to use the mark. ${ }^{63}$ The second step entails making actual use of the mark in commerce. ${ }^{64}$

The above statement suggests that the "two-step procedure" differs little from traditional use-based registration. Although the ITU application process represents a theoretical divergence from use-based trademark registration, both systems use similar application procedures. ${ }^{65}$ The only real distinction between the two is that ITU applicants do not provide actual specimens of mark use because they have not yet used the mark. ${ }^{66}$ Instead, a drawing of the trademark suffices. ${ }^{67}$ Absent anything further, one might question why any applicant would choose to pursue registration based on an intent to use a mark. The answer,

57. 15 U.S.C. $\$ 1051$ (d)(1) (1994); see also Leeds, supra note 1, at 273-75 (explaining the notice of allowance). A notice of allowance does not have an antecedent in use-based proceedings, but is comparable in time to the issuance of a registration in the use-based proceeding. Id. at 274.

58. 15 U.S.C. $\$ 1051$ (d) (1994).

59. Id. $\S 1051(\mathrm{~d})(2)$. One interesting practical note regarding extensions involves the period in which a declaration of use is considered. Under 37 C.F.R. $\$ 2.89(\mathrm{e})(1)(1994)$, an applicant is allowed only one extension after the declaration of use is filed. Filing this extension is very important, because a second declaration may have to be filed if the first is rejected by the examining attorney. Some attorneys seem to file the declaration of use and an extension simultaneously, anticipating this need for additional time. However, this extension is it; if the declaration and an extension are filed simultaneously, the single extension allowed has been used. Thus, if the six-month period expires prior to the examiner's review of the declaration of use, no more extensions are permitted.

The manner in which extensions should be filed to maximize the amount of time one has, and to minimize malpractice risk is as follows: File an extension and file the declaration a few days later. Then, file another extension at the end of that six-month period. The PTO's Trademark Assistance Center, which helped the author unravel 37 C.F.R. \& 2.89, can be reached at (703) 308-9500 ext. 111.

60. Id; see also 1 GILSON, supra note $1, \S 3.04[3]$, at 3-93 to -96 (discussing the difference between the Principal and Supplemental Register).

61. 1 GILSON, supra note $1, \S 3.04$ [2][a], at 3-89.

62. See supra note 49 for a discussion of the meaning of the phrase "bona fide intent."

63. 1 GILSON, supra note $1, \S 3.04[2][a]$, at 3-89.

64. Id.

65. Eck, supra note 4 , at $389-90$.

66. Id. "With the exception of those requirements which relate to use of the mark in commerce, other aspects of section 1(b) mirror the relevant language of the Lanham Act's current provisions relating to use-based applications, including the requirement that a drawing of the mark be provided." Id. at 389 .

67. Id. 
and the heart of the ITU system, lies in section $7(c)^{68}$ of the Lanham Act, the constructive use provision.

Constructive use is an artificial concept that allows an ITU applicant to claim the date that the initial ITU application was filed as the first date the mark was used in commerce, even though in reality, the mark may not have been used until much later. ${ }^{69}$ Under section 7(c), an applicant can "construct" use of the mark from filing. Filing an ITU application has the same legal effect as the earliest actual use, or priority, of a trademark at common law. ${ }^{70}$ As a result, an ITU applicant can claim the date of filing as the "priority" date for the purpose of determining exclusive rights when two marks conflict.

Priority, or prior use,$^{71}$ is a key concept in trademark law. The exclusive right to a distinctive mark belongs to the individual who first uses the mark in connection with a particular line of business. ${ }^{72}$ Thus, the earliest use of a mark is generally "equated with ownership of the mark."73 The earliest user is said to have priority in the mark.

Priority often determines the outcome of disputes involving marks. For example, the PTO will not register a mark if another confusingly similar ${ }^{74}$ mark has priority. ${ }^{75}$ Priority also extends to inter partes disputes. Generally, the prior user of a mark will prevail in opposition or infringement proceedings against a subsequent user of a confusingly similar mark. ${ }^{76}$ The prior user is referred to as the senior user, and the subsequent user is the junior user.

Historically, priority has been determined by the first date the mark was actually used in commerce. ${ }^{77}$ The mark had to be affixed to some good and sold in commerce; thus, the accrual of trademark rights has entailed a "race to the

68. 15 U.S.C. § 1057(c) (1994).

69. See id.; see also Leeds, supra note 1, at 281-82.

70. TRC Report, supra note 10, at 379 n.8.

71. "First use" and "prior use" have the same meaning: being the first individual to use a trademark in commerce. See Talk to Me Prods., Inc. v. Larami Corp., 804 F. Supp. 555, 559 (S.D.N.Y. 1992).

72. McLean v. Fleming, 96 U.S. 245 (1877).

73. 1 GILSON, supra note $1, \S 3.03[2][\mathrm{c}]$, at $3-67$ to -68 .

74. "Confusing similarity," or "likelihood of confusion," is another fundamental concept in trademark law. Because the aim of trademark law is to prevent consumers from confusing two products with similar marks, the legal standard for infringement is whether two marks are likely to be confused. See In re E. I. du Pont de Nemours \& Co., 476 F.2d 1357 (C.C.P.A. 1973) (setting out the test for likelihood of confusion). If the marks are confusingly similar, the first user of the mark prevails. 1 GILSON, supra note $1, \& 3.03[2][$ a], at 3-65 to -66 .

75. 15 U.S.C. \& 1052(d) (1994). Technically, one needs to prove only use analogous to trademark use, not prior use, to successfully oppose a trademark registration under $\S 2$ (d). PacTel Teletrac v. T.A.B. Sys., 32 U.S.P.Q.2d 1668, 1671 (T.T.A.B. 1994). Use analogous to trademark use is a lower standard to prove than prior use. Id.

76. See 1 GILSON, supra note $1, \S 3.03[2][a]$, at 3-65 to -66 ("As between conflicting claims to the same mark or confusingly similar marks, the prior user is virtually certain to prevail."); see also McLean v. Fleming, 96 U.S. 245 (1877).

77. See United Drug Co. v. Rectanus Co., 248 U.S. 90, 97 (1918) ("the right to a particular mark grows out of its use"). 
market place." 78 The priority of ITU applicants, however, is determined by the date the ITU application is filed, not the date of use. ${ }^{79}$ Thus, the application, not use, is the harbinger of rights. ${ }^{80}$ As a result, the ITU registrant can claim priority over anyone who made actual use of the same mark between his application and registration date, even if the ITU registrant had not yet made actual use of the mark in commerce. ${ }^{81}$

Several policy goals underlie the constructive use provision of section 7 (c). First, it increases certainty in the acquisition of trademark rights. ${ }^{82}$ An applicant can rely on the date of filing and not worry about mark pirating during the registration period. ${ }^{83}$ Otherwise, a third party could steal a mark published in the Official Gazette without penalty. ${ }^{84}$ Further, unlike common law priority, which can be limited to a particular locale ${ }^{85}$ section 7 (c) confers nationwide priority upon the registrant. ${ }^{86}$ Nationwide priority fosters certainty ${ }^{87}$ and encourages registration ${ }^{88}$ because subsequent users of the mark cannot claim priority in a limited geographical area. Finally, the provision increases trademark responsibility. Because a user of a mark will not gain common law rights if some ITU registrant pre-dates his use, the provision contains an incentive to conduct trademark searches prior to use. ${ }^{89}$

The importance of constructive use cannot be underscored sufficiently. "Constructive use is essential for an [ITU] application. Without it, the application would be an easy target for pirates, vulnerable also to priority claims of anyone else whose use began after applicant's filing date but before applicant's use." 90 Perhaps because of its importance, this section is the source of tension within the ITU system. ${ }^{91}$

78. 1 GILSON, supra note 1, §3.03[2][d], at 3-69 (citing Holsum Bakeries, Inc. v. General Baking Co., 228 F. Supp. 962 (E.D. La. 1964)).

79. See id. \& $1.04[4][\mathrm{C}][\mathrm{iii}][\mathrm{B}]$, at $1-56$ to -66 .

80. Stephen L. Carter, The Trouble with Trademark, 99 YALE L.J. 749, 781 (1990).

81. Id. at 781-82. For an illustration of this concept, see id. at 782-83. 82.

82. S. Rep. No. 100-515, supra note 13, at 29-30, reprinted in TLRA HISTORY, supra note 13, at 181 -

83. Id.

84. Id.

85. See Standard Oil Co. v. Osage Oil \& Transp., Inc., 10 U.S.P.Q.2d 1554, 1557 (N.D. Okla. 1988).

86. 15 U.S.C. \& 1057(c) (1994).

87. S. Rep. No. 100-515, supra note 13, at 29, reprinted in TLRA HISTORY, supra note 13, at 181.

88. Eck, supra note 4, at 393.

89. Id.

90. TRC Report, supra note 10, at 397.

91. See infra notes $164-68$ and accompanying text (arguing that constructive use prevents meaningful damage determinations). 


\section{III}

THE REMEDY HOLE

\section{A. The Origins of the Remedy Hole}

One issue that plagued Congress during the formation of the ITU system was the scope of rights it should accord an ITU applicant. ${ }^{92}$ For instance, imagine $\mathrm{P}$ has filed an ITU application for the mark BRAVO used on cheese. $^{93}$ During the application process, perhaps before the mark is published in the Official Gazette, D begins using the mark BRAVO on cheese in commerce. Prior to registering the mark, what can P do to prevent D's further use of the mark? The answer is surprising: absolutely nothing.

This conclusion was reached in a series of recent federal cases. Courts faced with this issue have held that an ITU applicant could obtain neither injunctive relief nor monetary remedy to prevent a third party from using the mark until the applicant's mark was registered. ${ }^{94}$ During the period between filing an application and receiving registration, the ITU applicant has no federal remedy against third-party users of the mark..$^{95}$ Rather, the applicant must wait until his registration has been issued to vindicate his rights through a federal remedy. ${ }^{96}$

Two rationales underlie this structure of remedies. The first rationale is premised on jurisdiction. Federal subject matter jurisdiction is not authorized under the Lanham Act for pre-registration questions. ${ }^{97}$ Rather, federal jurisdiction is conferred when the mark is registered. ${ }^{98}$ According to one court, the ITU provisions do not change this jurisdictional framework. ${ }^{99}$ These provisions "merely change the law as to when an 'application' for registration may first be filed. There is no change as to when registration, which triggers federal jurisdiction, takes place."100 Because the application procedure, and not

92. See 2 MCCARTHY, supra note $9, \S 19.08[1][d]$, at 19-58 to -61 .

93. This example is an adaptation of the examples proffered by the United States Trademark Association. TRC Report, supra note 10, at 398-99.

94. See, e.g., Talk to Me Prods., Inc. v. Larami Corp., 804 F. Supp. 555, 559-60 (S.D.N.Y. 1992) ("An application may confer a right of priority, but this is only triggered by registration .... [The] mark is not registered. Until it is, [the plaintiff] cannot rely on the constructive use provision of the new Act."); Windows User, Inc. v. Reed Bus. Publishing Ltd., 795 F. Supp. 103, $107-08$ (S.D.N.Y. 1992) ("Congress expressly provided that the [constructive use priority rights] are '[c]ontingent on the registration of a mark on the principal register."' (quoting 15 U.S.C.A. \$1057(c) (1994))); Fila Sport, S.p.A. v. Diadora Am., Inc., 141 F.R.D. 74, 79 (N.D. Ill. 1991) ("There is no statement in that statute to indicate that mere application under this new [ITU] section will suffice to grant the applicant rights of access to the federal court before the registration is granted.").

95. 2 MCCARTHY, supra note 9, \$19.08[1][a], at 19-54 to -57.

96. Id.

97. Fila, 141 F.R.D. at 78.

98. Id.; see also 15 U.S.C. $\S 1114$ (1994).

99. Fila, 141 F.R.D. at 78.

100. Id. 
jurisdictional provisions, were changed, ${ }^{101}$ the Lanham Act still specifies registration as the event triggering such jurisdiction. ${ }^{102}$

If jurisdiction were the only obstacle preventing relief, an ITU applicant could go to state courts for relief or could sue under a different theory of jurisdiction, such as diversity. ${ }^{103}$ However, a second rationale for denying relief has been advanced. The second, or rights-based rationale, addresses what many believe to be the real problem inherent in pursuing a remedy as an ITU applicant: The Lanham Act does not provide a cause of action prior to registration. According to this rationale's proponents, Congress intended to bestow rights on individuals during the application process, but these rights were to vest only upon registration of the mark. ${ }^{104}$ As a consequence, redress occurs retrospectively; ${ }^{105}$ the ITU registrant receives injunctive relief and/or damages only after the mark is registered, perhaps long after the initiation of injury. ${ }^{106}$

This rights-based rationale was defined in two cases decided in the Southern District of New York. The first case involved the mark WINDOWS USER used on magazines. ${ }^{107}$ In this case, the plaintiff had not used the mark but had filed an ITU application. ${ }^{108}$ The defendant was actually using the mark in commerce. ${ }^{109}$ To prevent the defendant's further use of the mark, the plaintiff sought injunctive relief. ${ }^{110}$ The plaintiff claimed that he had priority rights in the mark and was entitled to relief because his ITU filing date was prior to the defendant's use. ${ }^{111}$

The court held that the plaintiff had no right to injunctive relief based on the priority established by the ITU application. ${ }^{112}$ The court reviewed the history behind the ITU system and concluded that the application process itself conferred no rights. ${ }^{113}$ After detailing congressional intent behind constructive use, the court noted that "Congress expressly provided that the above described rights [defined in section $7(\mathrm{c})]$ are '[c]ontingent on the registration of a mark on

101. The Senate Judiciary Committee amended the sections of the Lanham Act dealing with injunctive relief specifically to ensure that an ITU applicant could not obtain injunctive relief until after registering the mark. S. REP. NO. 515, supra note 13, at 30, reprinted in TLRA HISTORY, supra note 13 , at 182 .

102. Id; see, e.g., 15 U.S.C. \$§ 1114(1)(a), 1116, 1125(a) (1994).

103. See Fila Sport, S.p.A. v. Diadora Am., Inc., 141 F.R.D. 74, 80 (N.D. Ill. 1991). In fact, Judge

Alesia in the Fila decision explicitly recommended that Fila allege diversity jurisdiction. Id.

104. See Windows User, Inc. v. Reed Bus. Publishing, Ltd., 795 F. Supp. 103, 107-08 (S.D.N.Y. 1992).

105. Talk To Me Prods., Inc. v. Larami Corp., 804 F. Supp. 555, 560 (S.D.N.Y. 1992).

106. Id.

107. Windows User, Inc., 795 F. Supp. at 103.

108. Id . at 108. The plaintiff's application had been rejected by the PTO on the ground that the mark WINDOWS USER was descriptive. Id. at 105.

109. Id.

110. Id. at 106.

111. Id. at 107 .

112. Id. at 108 .

113. Id. 
the Principal Register."'114 Because the plaintiff had not registered the mark, he had no rights to the mark. ${ }^{115}$

In a subsequent case, ${ }^{116}$ the court again refused to recognize the rights of an ITU applicant. ${ }^{117}$ In this case, the plaintiff filed an infringement action, ${ }^{118}$ claiming that the defendant's use of the mark SUPER SOAKER infringed its rights to the mark SOAKER for water guns. ${ }^{119}$ The plaintiff argued that these rights ${ }^{0}$ were conferred by its ITU application; the date of the ITU application pre-dated the defendant's use of the mark. ${ }^{120}$

The court rejected the plaintiff's argument. ${ }^{121}$ It began its analysis by noting that the plaintiff had not been issued a registration to the mark SOAKER. ${ }^{122}$ Advocating a "plain reading" of section 7(c), the court held that "[a]n application may confer a right of priority, but this is only triggered by registration .... [The plaintiff's] mark is not registered. Until it is, [the plaintiff] cannot rely on the constructive use provision of the new Act." ${ }^{123}$

To justify its decision, the court reviewed the legislative history behind the constructive use provision and concluded that Congress did not "clearly express" an intention contrary to the plain meaning of the statute. ${ }^{124}$ Therefore, the court ruled that until a mark is registered, "the contingency expressly required by Congress has not come to pass," and an ITU applicant "cannot derive any rights from section 1057(c)."125 The court did recognize that its holding would limit the benefits of the ITU application system. ${ }^{126}$ Nevertheless, it reasoned that the main purpose of section 7(c) would be preserved. ${ }^{127}$ This purpose, according to the court, was "foster[ing] [ITU] applications."128

As a result of these decisions, ITU applicants do not seem to have redress against individuals who use the same or a confusingly similar mark. Relief is afforded only after registration. ${ }^{129}$ Thus, to vindicate his rights, the ITU applicant must proceed with the registration process and seek remedy in the future, if his registration is issued.

114. Id.

115. Id.

116. Talk To Me Prods. Inc. v. Larami Corp., 804 F. Supp. 555 (S.D.N.Y. 1992).

117. Id. at 559-60.

118. Id. at 557 .

119. Id.

120. Id. at 559 .

121. Id.

122. Id. at 558.

123. Id. at 559-60 (citing Windows User, Inc. v. Reed Bus. Publ., Ltd., 795 F. Supp. 103, 107 (S.D.N.Y. 1992)).

124. Id. at 560 .

125. Id.

126. Id. ("[Registration] does limit, to be sure, the benefits gained from filing an [ITU] application.").

127. Id.

128. Id.

129. See 2 MCCARTHY, supra note $9, \S 19.08[1][a]$, at 19-54 to -57 . 
This result appears to be consistent with congressional intent. ${ }^{130}$ Originally, the Senate draft of the TLRA allowed ITU applicants to sue and courts to withhold final judgment pending registration of the mark. ${ }^{131}$ However, this conditional judgment provision was omitted from the final legislation. ${ }^{132}$ Commentary included in the final draft of legislation explains this omission: ${ }^{133}$

A provision to defer entry of final judgments in certain [ITU] cases ... was not included in the final legislation due to the House Judiciary Committee's concern that the courts would be hearing cases not ripe for decision and its objections to applicants who have not perfected their rights filing suit. ${ }^{134}$

As a result, section 34 of the Lanham Act $^{135}$ gives courts the power to grant injunctions to support the rights of "the registrant of a mark." 136

This remedy hole was recognized as problematic in the legislative history. The Senate passed an amendment that permitted ITU applicants to pursue lawsuits to the point of final judgment, but precluded final judgment until registration. ${ }^{137}$ However, the Subcommittee on Courts, Civil Liberties, and the Administration of Justice deleted these provisions. ${ }^{138}$ The Committee explicitly recognized that this deletion might render the rights of ITU applicants meaningless. ${ }^{139}$

\section{B. The Implications of the Remedy Hole: Liability and Compensation}

In practice, the remedy hole is problematic both in terms of liability and compensation. Because ITU applicants cannot prevent others from using their marks, their ability to hold others liable for infringement is threatened. Moreover, unlike use-based injuries, the damages of ITU applicants are so tentative and speculative that prohibiting injunctive relief may ensure that ITU applicants are undercompensated.

130. Cf. Carter, supra note 80 , at 784 (arguing that the Lanham Act under the ITU provisions bestows trademark rights without requiring use).

131. See 2 MCCARTHY, supra note 9, §19.08[1][a], at 19-55.

132. See The Trademark Act of 1946 (Lanham Act) as amended by Public Law 100-667 (Interlineated Text with Commentary), reprinted in TLRA HISTORY supra note 13, at 365.

133. The commentary noted that

because rights in a mark are not created unless and until the mark is used, and consumer confusion cannot arise without such use, a final judgment in favor of an [ITU] applicant who must establish constructive use to prevail will not be entered until the applicant's mark is registered and its rights are thereby perfected.

S. Rep. No. 100-515, supra note 13, at 30, reprinted in TLRA HISTORY, supra note 13, at 182.

134. See The Trademark Act of 1946, the Lanham Act, as amended by Public Law 100-667 (Interlineated Text with Commentary), reprinted in TLRA HISTORY, supra note 13, at 365; see also TRADEMARK LAW REVISION ACT OF 1988, H.R. REP. No. 100-1028, at 4 (1988).

135. 15 U.S.C. \& 1116 (1994).

136. Id. (emphasis added).

137. H.R. REP. No. 100-1028, at 4.

138. Id. " Permitting a plaintiff to sue before use occurs . . . raises serious questions about abuse of the judicial system, about whether federal jurisdiction and a case or controversy exists, and about whether such a case is "ripe." ).

139. Id. 
The liability threat stems, in part, from the equities that users obtain in the eyes of the court vis-à-vis non-users. In an attempt to soften the harsh application of calendar priorities, courts are allowed to consider equity in determining the rights of mark users versus the rights of ITU registrants. ${ }^{140}$ The Senate Judiciary Committee in no uncertain terms intended that individuals who use an ITU applicant's mark should be allowed some equitable considerations. ${ }^{141}$ Theoretically, the user of the mark has as significant an investment as the ITU applicant. ${ }^{142}$ Thus, if an ITU registrant "drags his heels" during the application process at the same time that a third party vigorously uses his mark, equitable considerations may require recognizing the third party's priority over the ITU registrant. ${ }^{143}$ Equitable considerations could trump the ITU registrant's priority and rights. ${ }^{144}$

There is also no guarantee that the ITU registrant will be able to prove all the substantive elements of any infringement claim. To prove infringement, an ITU registrant must, in addition to demonstrating priority, show that his and the third party's mark are likely to be confused by consumers. ${ }^{145}$ If both are using the mark in a limited geographical area, the ITU registrant may be afforded no relief ${ }^{146}$ until he demonstrates that the two marks will be circulated within the same purchasing community. ${ }^{147}$

The inability of an ITU applicant to vindicate his rights against the third parties who use his mark after his constructive use date diminishes the value of the entire ITU system. The force of the ITU system lies in the constructive use provisions in section 7(c) of the Lanham Act. ${ }^{148}$ Authors who dismiss the notion that an ITU applicant's mark can be pirated base their arguments on a

140. 2 MCCARTHY, supra note $9, \S 19.08[1]$ [d], at 19-58 to -61; see also Chandon Champagne Corp. v. San Marino Wine Corp., 335 F.2d 531, 534 (2d Cir. 1964).

141. S. REP. NO. 100-515, supra note 13, at 30, reprinted in TLRA HISTORY, supra note 13 , at 182. The committee report states that

the committee does not intend ... for constructive use to replace equity. Equity has been and will continue to be the core of U.S. trademark jurisprudence. As the courts have refused to make 'calendar priority' based on actual commercial use of a mark determinative of rights if Id.

doing so will cause inequity, they should not react differently with constructive use.

142. Id.

143. See 2 MCCARTHY, supra note 9 , § 19.08[1][d], at 19-58 to -61 .

144. Id.

145. S. Rep. No. $100-515$, supra note 13 , at 30 , reprinted in TLRA HISTORY, supra note 13 , at 182 ("[R]ights in a mark are not created unless and until the mark is used, and consumer confusion cannot arise without such use.").

146. 2 MCCARTHY, supra note 9, § 19.08[1][e], at 19-62 n.16 (noting that "[t]he nationwide 'constructive use' of section 7 (c) only relates to priority and does not create a real presence sufficient to create a likelihood of confusion." (citing Report of the Trademark Review Commission, 77 TRADEMARK REP. 375, 403 (1987))).

147. S. Rep. No. $100-515$, supra note 13 , at 30 , reprinted in TLRA HISTORY, supra note 13 , at 182 ("[C]onstructive use will not foreclose defenses such as those based on the descriptive, surname, or geographic character of the mark."); 2 MCCARTHY, supra note 9, \& 19.08[1][e], at 19-62 (citing Holiday Inns, Inc. v. Holiday Motel, Inc., 200 U.S.P.Q. 360 (D. Mont. 1978)).

148. See supra note $90-91$ and accompanying text. 
strenuous application of section $7(\mathrm{c})$ by the courts. ${ }^{149}$ However, section 7(c) was not intended to be air tight. ${ }^{150}$ An ITU registrant's priority and rights can be defeated, for example, by equitable considerations or geographic limitations. ${ }^{151}$ Thus, it is quite possible that an ITU registrant may incur the costs of the application process yet receive little benefit. ${ }^{152}$

Perhaps more troubling is the potential inability of ITU applicants to receive adequate compensation under the current scheme. ${ }^{153}$ Under the Lanham Act, a court can award the infringed ITU plaintiff who has registered his mark: (1) the defendant's profits; (2) any damages sustained by the plaintiff; and (3) the costs of the action. ${ }^{154}$ These relief provisions were intended to compensate for an "injury to or loss of reputation or goodwill, lost sales, lost profits, the expense of preventing customers from being deceived, and any related expenses." 155 Although the language of the statute seems to imply that an award is cumulative, encompassing all of these injuries, the courts usually make a plaintiff choose between his damages or the defendant's profits. ${ }^{156}$ These provisions remained unchanged by the TLRA and apply to ITU and use-based registrants equally. ${ }^{157}$

A plaintiff who attempts to recover his own damages can recover for lost profits and/or diminished trademark value. ${ }^{158}$ Lost profits can be demonstrated

149. See, e.g., Carter, supra note 80 , at 784 ("[O]ther firms will borrow the mark at their peril, for the applicant might use the mark, perfect its filing, and register the mark at any time. Once registration is accomplished, the applicant has nationwide priority as the constructive first user and can enforce all the substantive rights that the Lanham Act provides."); Leeds, supra note 1, at 282 ("Constructive use will prevent a third party from acquiring common law rights in a mark after its effective date."); TRC Report, supra note 10, at 397 ("Constructive use is essential for an [ITU] application. Without it, the application would be an easy target for pirates, vulnerable also to priority claims of anyone else whose use began after applicant's filing date but before applicant's use.").

150. S. Rep. No. 100-515, supra note 13, at 30, reprinted in TLRA HISTORY, supra note 13, at 182.

151. Id.

152. See, e.g., TRC Report, supra note 10, at 405 :

On the issue of priority, some flexibility would be lost but some certainty would be gained by according constructive use to an applicant's filing date. Priority is a threshold fact issue for which we need more certainty of resolution. But this would not take equity out of an infringement suit. A plaintiff asserting constructive use would not be assured victory; it would still have to establish a protectible interest and likelihood of confusion in defendant's territory to prevail.

153. See 15 U.S.C. $\$ \S 1116-18$ (1994).

154. 15 U.S.C. $\$ 1117$ (a) (1994). This section reads:

When a violation of any right of the registrant of a mark registered in the Patent and Trademark Office ... shall have been established ... the plaintiff shall be entitled, subject to the provisions of sections 1111 and $\mathbf{1 1 1 4}$ of the title, and subject to the principles of equity, to recover (1) defendant's profits, (2) any damages sustained by the plaintiff, and (3) the costs of the action .... In assessing damages the court may enter judgment, according to the circumstances of the case, for any sum above the amount found as actual damages, not exceeding three times such amount.

155. 1A GILSON, supra note $1, \S 8.08[2]$.

156. Id.

157. Compare 15 U.S.C. $\$ 1117$ (1988) with id. (1994). Section 1117 (b) was added in 1984, however, to compensate victims of counterfeiting. $1 \mathrm{~A}$ GILSON, supra note $1, \S 8.08[1]$, at 8-172.5 to -175 .

158. 1A GILSON, supra note $1, \S 8.08[2]$, at 8-176 to -182 . 
by presenting evidence of actual or reasonably approximated losses. ${ }^{159}$ Demonstrating the diminished value of a mark may be more difficult. The value of a trademark is derived from the goodwill of the business that owns the mark. ${ }^{160}$ This goodwill is determined by "the company's method of doing business, its concern for its customers, its attitudes, honesty, and integrity."161 The value of long-standing goodwill manifested in a trademark is extraordinary; for example, in 1967 the Coca-Cola company listed the value of the marks COCA-COLA and COKE at $\$ 3$ billion. ${ }^{162}$ Nevertheless, because the value of the mark is based on intangible qualities, trademark valuation is speculative. ${ }^{163}$

In particular, ITU plaintiffs may have difficulty proving damages, either to profits or to the mark. Unlike use-based registrants, ITU registrants cannot use their marks for a long period of time prior to the initiation of a law suit. ${ }^{164}$ As a result, the ITU applicant may not have a lengthy period of time to build up a sizeable market or goodwill. This lack of data prevents any meaningful determination of the applicant's potential profits or the mark's potential value to the ITU registrant. ${ }^{165}$

Even if there were significant data, any resulting forecast of the mark's value would likely be inaccurate. ${ }^{166}$ Forecasting the potential value of a plaintiff's mark requires estimating the goodwill value of the mark and similar marks. ${ }^{167}$ However, use of the mark by a third party may negatively influence the public's perception of the mark. Because the estimated variables are highly interrelated, the true value of the mark cannot be forecast accurately. ${ }^{168}$

159. See Lindy Pen Co., v. Bic Pen Corp., 982 F. 2d 1400 (9th Cir. 1993) (holding that a plaintiff must show reasonably forecast profits to establish damages under lost profits method); see also $1 \mathrm{~A}$ GILSON, supra note $1, \S 8.08[2]$, at 8-178 (noting that the plaintiff is not precluded from recovering for lost profits if it cannot show actual damages precisely; rather, an approximation will suffice).

160. 1 GILSON, supra note $1, \S 1.03[7]$, at $1-36$ to -37 (noting that the relationship between the value of trademarks and goodwill is so unique that a trademark cannot be assigned apart from its goodwill, and the trademark cannot exist apart from the business in which it is used).

161. JOHN D. OATHOUT, TRADEMARKS 39-40 (1981). "Goodwill is all the positive but intangible things a company wants the public to think of it. In short, it is image and character, with a trademark as its symbol." Id. at 40 .

162. Id.

163. Id.

164. In the ITU system, years can pass between the date the Notice of Allowance is issued and the date of registration. During this time, the ITU applicant is allowed to perfect his right by making use of his trademark and filing a declaration of use. Use-based registration does not contain this lag because use of the mark occurs prior to filing an application for registration. See supra notes 38-40 and accompanying text.

165. See George G. Judge et al., InTRoduction to the Theory and Practice of ECONoMETRICS 71 (1988). The larger a sample size is, or the more data one has, the more accurate, or less biased, a statistical estimate will be. Id. at 69-71. For a mathematical proof that estimates collapse around their true parameters as the sample size increases, see $i d$. at 84-85.

166. See id. at 59-61.

167. See supra notes $160-63$ and accompanying text.

168. JUDGE ET AL., supra note 165 , at $59-60$. The harmful interrelationship between variables is called "multicollinearity." Id. As a result of multicollinearity, forecasts are skewed and important variables may appear to be statistically unimportant. See generally id. at 59-86 (explaining the problems of multicollinearity, as well as methods for detecting and eliminating it). 
The second method of compensation, requiring the defendant to disgorge his profits, is also inadequate to compensate ITU registrants. Generally, plaintiffs who ask for the defendant's profits must go beyond a mere showing of infringement to receive an accounting for profits. ${ }^{169}$

A defendant's infringement of plaintiff's trademark does not automatically entitle plaintiff to an accounting [of the defendant's profits]. ... Rather, an accounting is appropriate if defendant "is unjustly enriched, if the plaintiff sustained damages from the infringement, or if an accounting is necessary to deter a willful infringer from doing so again." 170

The rationale for awarding the defendant's profits is that "the infringer should not be permitted to retain the fruits of his wrongdoing."171 The hidden assumption behind this rationale is that the defendant is trading on the plaintiff's already established goodwill. ${ }^{172}$ In other words, the defendant profited because he was trying to capture or actually captured confused customers who thought they were buying the plaintiff's product.

In the ITU case, this assumption is faulty, and this method of compensation is wholly unrelated to the plaintiff's injury. By definition, injury to the ITU applicant occurs before the applicant has used the mark in commerce. The ITU applicant has not established any goodwill at the time of infringement. As a result, the defendant is not trading on the ITU applicant's goodwill because none exists. Instead, he is creating his own goodwill. Because the defendant's profits are wholly unrelated to the plaintiff's activities, they are not a good measure of the plaintiff's damages or potential profits. ${ }^{173}$ There is no assurance that the ITU applicant is being properly compensated.

Because of these "forecasting problems," the ITU applicant cannot be properly compensated. ITU applicants cannot prevent the occurrence of compensable injury by obtaining injunctive relief. As a result, the current structure of the ITU system may ensure that an infringed ITU applicant will never receive adequate compensation.

\section{Remedying the Hole}

The problems created by the remedy hole can be resolved by a change in the relevant statute or by a shift in judicial interpretation. Under either

169. See, e.g., Weight Watchers Int'l, Inc. v. Stouffer Corp., 744 F. Supp. 1259, 1288-89 (S.D.N.Y. 1990) (requiring strenuous proof by the plaintiff to recover the defendant's profits); see also 1A GILSON, supra note $1, \$ 8.08[3]$, at $8-182$ to -187 (arguing that the courts balance the defendant's intent and conduct when awarding an accounting for profits).

170. Weight Watchers Int'l, 744 F. Supp. at 1288-89 (citing W. E. Bassett Co. v. Revlon, Inc., 435 F.2d 656, 664 (2d Cir. 1970)).

171. 1A GILSON, supra note $1, \S 8.08[3]$, at 8-185.

172. See Weight Watchers Int'l., 744 F. Supp. at $1288-89$ ("Stouffer would have been unjustly enriched if its sales of Lean Cuisine items were attributable to its infringing use of the Weight Watchers name.").

173. JUDGE ET AL., supra note 165, at 171-74. Such a poor statistical "fit" is evidenced by a low Rsquared value; if the defendant's profits were used to forecast the plaintiff's lost profits, the resultant R-squared would be very low because the defendant's profits are not a good explanatory variable. Id. Thus, they should not be used as the sole means of calculating the plaintiff's damages. 
resolution, one of two things must occur: Equitable considerations must be removed from the determination of liability or constructive use must be extended to the application period.

One solution would involve a change in the application of equitable principles. In order to ensure ITU applicants certainty in the registration process, the courts can limit the application of such principles to a particular set of circumstances. A court should consider equitable principles only if a defendant's initial use of the ITU applicant's mark begins after the filing date of the ITU application but before the mark is published in the Official Gazette. ${ }^{174}$ Only in this situation is the defendant completely unable to conduct a trademark search and discover that the mark is "reserved."

A stronger alternative may lie in a complete statutory prohibition of the resort to equitable considerations. A weak section $7(\mathrm{c})$ is not as problematic if the ITU applicant is guaranteed a successful infringement suit after registering his mark. This result can be achieved by a simple statutory revision: Prohibit the consideration of equitable principles in inter partes disputes involving ITU applicants.

Unfortunately, prohibiting equitable considerations does not solve the ITU registrant's remedy problem. Guaranteeing the ITU applicant a successful outcome in the future does not guarantee him a just and adequate outcome. In other words, restricting equity considerations relieves the liability problem, but the compensation problem remains.

The simplest relief to both problems would require a shift in the current interpretation of section 7(c). Such a shift has a basis in recent Trademark Trial and Appeal Board ("TTAB") decisions. ${ }^{176}$ The TTAB has interpreted section $7(\mathrm{c})$ in a manner wholly divergent from the federal courts: ITU applicants can assert constructive use at the date of application. ${ }^{17}$

In a recent opinion, the TTAB held that an ITU applicant is allowed to rely upon his constructive use date prior to registering the mark. ${ }^{178}$ The Board examined the history and purpose behind the ITU provisions and concluded that these purposes-protecting the applicant from pirates and encouraging filing of applications and searching trademark records ${ }^{179}$ - could be served only

174. See 2 MCCARTHY, supra note $9, \S 19.08$ [1][d], at 19-58 to -61 (considering this particular fact pattern and arguing that this circumstance justifies the court's consideration of equitable principles). If a third party uses a mark in commerce prior to an ITU applicant's filing date, current law dictates that the third party has the rights to the mark. No issues unique to the ITU system arise under this fact pattern. See supra notes 107-08.

175. Id.

176. See Zirco Corp. v. American Telephone and Telegraph Co., 21 U.S.P.Q.2d 1542, 1544 (T.T.A.B. 1992).

177. Id.

178. Id. ("[T]here can be no doubt but that the right to rely upon the constructive use date comes into existence with the filing of the [ITU] application and that an [ITU] applicant can rely upon this date in an opposition brought by a third party asserting common law rights.").

179. Id. 
by allowing an ITU applicant to assert his constructive use rights at the time of filing. ${ }^{180}$

The accuracy of this interpretation may be reflected in the necessity of the Board's decision: "If an [ITU] applicant were not allowed to rely upon the constructive use date prior to actual use and registration of its mark, it would be rendered defenseless in any opposition against the registration of its mark."181 Thus, unless ITU applicants can rely on constructive use, third parties can block the ITU applicants' registration, and constructive use rights would never vest.

Alternatively, if courts are reluctant to confer wholesale constructive use rights on ITU applicants, they could temper these rights by requiring strenuous proof of the likelihood of success on the merits for injunctive relief. ${ }^{182}$ To qualify for injunctive relief, a plaintiff must prove "either a likelihood of success on the merits or that the balance of hardships tips decidedly in its favor." 183 ITU applicants could be subject to a heightened level of scrutiny-proof that registration of the mark is certain. ${ }^{184}$ To make this determination, courts could consider many factors, including the following: proof that the applicant has almost completed the registration process; the investment that the plaintiff has made in preparing for use of the mark or production of a good bearing the trademark; any advertising or use analogous to trademark use the applicant has made; any actual association of the mark with the applicant in the consuming public's mind; and the total number of marks for which the applicant has filed ITU applications. ${ }^{185}$

Although the courts and Congress have several roads from which to choose, one thing is certain: Under the current system, the ITU applicant has no registration certainty and a threat of incurring undercompensated injury if his mark is infringed prior to registration. Given these risks and the relative weakness of section 7(c), the ITU provisions do not provide any particular benefit and may cause economic harm to those who choose to invoke them. The potential ITU applicant might be in a superior position if he simply makes

180. Id. The Board explicitly left the constitutionality of this right to the federal courts. Id.

181. Id.

182. Because injunctive relief requires neither proof of actual consumer confusion nor actual injury to the plaintiff, an ITU applicant may be able to meet this standard of proof. See Weight Watchers Int'l., Inc. v. Stouffer Corp., 744 F. Supp. 1259, 1287-88 (S.D.N.Y. 1990).

183. Windows User, Inc. v. Reed Bus. Pub., Ltd., 795 F. Supp. 103, 107 (S.D.N.Y. 1992).

184. The Southern District of New York's decision in Windows User may have left open the possibility of ITU applicants obtaining injunctive relief based on strenuous proof of the applicant's likelihood of using the mark. $795 \mathrm{~F}$. Supp. at 108-09. The court examined whether this proof could be made in its particular case. Id. Thus, arguably, the court's holding is limited to that particular set of facts where the ITU applicant's application has been rejected. A different ITU applicant may make a sufficient showing of the likelihood of success on the merits.

185. These factors could also be used to show the tremendous hardship a plaintiff would suffer if injunctive relief were not granted, and the fitness of the record for judicial review. Thus, the same factors could be used to demonstrate that an action is ripe. See Abbott Labs. v. Gardner, 387 U.S. 136 (1967). 
use of the mark as soon as possible and follows the traditional methods of usebased trademark registration.

IV

\section{Bottomless Rights: The Extent of Exceptions TO SECTION 7(C)} PRIORITY

The lack of enforceable rights for an applicant is not the only problem emanating from section 7(c) of the Lanham Act. The section may be too strong in another respect, conferring too many rights to the ITU applicant. This skewed result occurs because of the dual purpose of section 7(c): It not only grants constructive use, but it defines the circumstances in which the right should be taken away.

Codified within section 7 (c) are very specific exceptions to the ITU registrant's constructive use priority. Under section 7(c), an ITU applicant does not have priority over an individual who has not abandoned his mark and, prior to the applicant's filing date,

(1) has used the mark;

(2) has filed an application to register the mark which is pending or has resulted in registration of the mark; or

(3) has filed a foreign application to register the mark on the basis of which he or she has acquired a right of priority, and timely files an application under section 44(d) to register the mark which is pending or has resulted in registration of the mark. ${ }^{186}$

Specifically under the first exception, section 7(c)(1), the ITU applicant does not have nationwide priority against a common law prior user of the mark. ${ }^{187}$ This exception to priority is justified on several policy grounds. One such justification is equity. ${ }^{188}$

According a filing date nationwide constructive use is policy-justified as against a subsequent user who either knew of, or could have searched, applicant's earlier trademark claim. A prior user, of course, cannot initially know of a later-filed application. It would thus be inequitable to permit that application to freeze the prior user's right to territorial expansion. ${ }^{189}$

Another justification is that the exception strikes a balance between conflicting goals of the TLRA. ${ }^{190}$ One goal of the TLRA is to encourage registration and decrease the likelihood of conflicting marks. ${ }^{191}$ A second goal is to prevent the abrogation of common law trademark rights. ${ }^{192}$ Constructive use encourages registration and protects an ITU applicant against subsequent users of the mark. ${ }^{193}$ However, section $7(\mathrm{c})(1)$ "explicitly leaves intact the

186. 15 U.S.C. $\S 1057(c)(1),(2),(3)(1994)$.

187. Id. $\$ 1057(\mathrm{c})(1)$.

188. TRC Report, supra note 10 , at 398.

189. Id.

190. See Trademark Law Revision Act of 1987: Hearings on S. 1883 Before the Comm. on the Judiciary, 100th Cong. 325 (1988) (response from Senator Hatch) [hereinafter Senator Hatch Response].

191. See id. at 278 (statement of Michael A. Grow).

192. Id.

193. Id. 
principle that prior common law users retain their rights vis-à-vis [ITU] provisions." 194 Thus, a balance is struck; the constructive use provision fosters certainty, while the exception retains the common law rights of prior users. ${ }^{195}$

The extent of these exceptions has not been the subject of intense judicial scrutiny. The legal standard necessary to qualify for the exception in section $7(c)(1)$ is still a partially open question. Only two cases have come close to dealing with the plethora of issues springing from this exception. ${ }^{196}$

The first decision to scratch the surface of section 7(c)(1) was Shalom Children's Wear, Inc. $v$. In-Wear A/S. ${ }^{197}$ In Shalom, the TTAB heard an opposition based on this section. ${ }^{198}$ The opposer claimed that it had used the ITU applicant's proposed mark, BODY GLOVE, for children's clothes prior to the applicant's filing date. ${ }^{199}$ The applicant argued that the opposer's use, drawings of the opposer's clothes with the mark displayed, was insufficient to create priority rights under section $7(c)(1)$ because the use was mere "token use." 200

The TTAB concluded that the opposer had made a showing sufficient to qualify for the exception. ${ }^{201}$ This showing was sufficient because under section $7(c)(1)$ "[q]uestions of priority and territorial rights involving prior users should be decided under current law."202 Furthermore, because this section contains no description of the type of use necessary to qualify for the exception, "use analogous to trademark use" was found sufficient to establish prior use under section $7(\mathrm{c})(1){ }^{203}$

Following this decision, the Southern District of New York further refined the meaning of section 7(c)(1) in Redisar Ltd. v. Virgin Enterprises, Ltd. ${ }^{204}$ The plaintiff in Redisar had filed an ITU application for use of the mark VIRGIN on cola. ${ }^{205}$ The defendant had used the same mark on products other than cola prior to the plaintiff's constructive use date. ${ }^{206}$ The court held that the defendant's use was sufficient to exempt it from the plaintiff's right of priority under section $7(\mathrm{c})(1) .{ }^{207}$

This holding was based on the lack of qualifiers within the exception. Because section 7(c)(1) reads "has used the mark" not "has used the mark in commerce on or in connection with the goods or services specified in the

194. Parker, supra note 34 , at 327.

195. See Senator Hatch Response, supra note 190, at 325-26.

196. See Redisar, Ltd. v. Virgin Enterprises, Ltd., 33 U.S.P.Q.2d 2020 (S.D.N.Y. 1995); Shalom Children's Wear, Inc. v. In-Wear A/S, No. 86, 459, 1993 TTAB LEXIS 16 (T.T.A.B. 1993).

197. 1993 TTAB LEXIS 16 (T.T.A.B. 1993).

198. Id.

199. Id. at *1-2.

200. Id. at *9-10.

201. Id. at *12.

202. Id. at *10 (quoting TRC Report, supra note 10 , at 398 ).

203. Id. at *11-13.

204. 33 U.S.P.Q.2d 2020 (S.D.N.Y. 1995).

205. Id. at 2021 .

206. Id.

207. Id. 
certificate," the court found that use of the mark on any good or service is sufficient to qualify for exception under section $7(\mathrm{c})(1){ }^{208}$

To date, no decision has addressed the level of similarity between marks sufficient to fall under this exception. For example, it is unknown if use of a confusingly similar mark falls within the exception of section $7(\mathrm{c})(1)$. Both Shalom and Redisar involved users of the same mark. ${ }^{209}$ Thus, it is unclear whether section $7(\mathrm{c})(1)$ should be interpreted to require the prior use of "the same or a confusingly similar mark," or "the same mark or its legal equivalent."

This difference is significant. If section $7(c)(1)$ is narrowly interpreted to require use of "the same mark or its legal equivalent," a skewed result occurs-the user with priority could be sued successfully. To prove infringement, the owner of a trademark must show priority over the user of a mark that is likely to be confused with its own. ${ }^{210}$ To qualify for exception from priority under a narrow interpretation of section $7(c)(1)$, the prior user of the confusingly similar mark must show that his mark is the legal equivalent of the trademark owner. This standard is higher than a confusing similarity or a likelihood of confusion standard. ${ }^{211}$ Thus, under a narrow interpretation of section 7(c)(1), a senior user might infringe a junior ITU registrant's mark because the marks are likely to be confused but not legally equivalent. ${ }^{212}$

This result is not tenable given the goals of trademark law. The purpose of the Lanham Act is both "to protect the public so it may be confident that ... it will get the product which it asks for and wants to get ... [ [and to] protect the [trademark] owner who has spent energy, time, and money in presenting to the public the product." 213 However, denying priority to users of a mark over later ITU registrants with confusingly similar marks does not serve either goal. In such a circumstance, ITU applicants could pick marks that are confusingly similar but not legally equivalent to an existing common law mark. Common law owners who have built a reputation and customer base would then be denied priority over the ITU applicant. In other words, the ITU applicant would be allowed to trade on the goodwill of a common law owner because of paper requirements. The public would be faced with the junior user's confusing mark, and the senior user would lose his investments.

This result is equally untenable given the goals of section $7(c)(1) \cdot{ }^{214}$ Prior users of a mark would be required to anticipate all future confusingly similar marks in order to protect their marks. However, the exception was drafted with the explicit recognition that this result was inequitable. ${ }^{215}$

208. Id.

209. See Redisar, 33 U.S.P.Q.2d at 2021; Shalom, 1993 TTAB LEXIS 16, at *2.

210. Astra Pharmaceutical Prod. v. Beckman Instruments, Inc., 718 F.2d 1201, 1205 (1st Cir. 1983).

211. Van Dyne-Crotty, Inc. v. Wear-Guard Corp., 17 U.S.P.Q.2d 1866, 1868 (Fed. Cir. 1991).

212. See id.

213. S. REP. No. 79-1333, 3-4 (1946); H. REP. No. 79-219, $2-3$ (1945).

214. See supra notes $190-95$ and accompanying text.

215. See TRC Report, supra note 10, at 398. 
The result is also inconsistent with clearly expressed congressional intent. Congress intended to resolve section 7(c)(1) priority questions under current law. ${ }^{216}$ The Senate Hearings refer to the rights of common law users vis-à-vis ITU registrants as analogous to those rights vis-à-vis use-based registrants. ${ }^{217}$ The TTAB, interpreting congressional intent, has held that section 7(c)(1) and section 2(d) of the Lanham Act should have the same legal effect. ${ }^{218}$ Section 2(d) of the Lanham Act allows users of the same or confusingly similar marks exception to a registrant's priority. ${ }^{219}$

Interpreting section 7(c)(1) narrowly and excepting only users of the same mark or its legal equivalent creates a discrepancy between the two analogous sections. Thus, the narrow interpretation of section 7(c)(1) is antithetical to the express intent of Congress; rather, section 7(c)(1) should be interpreted to except prior users of confusingly similar marks from an ITU registrant's nationwide priority.

\section{$\mathrm{V}$ \\ CONCLUSION}

For the first time in the history of the Lanham Act, an individual does not need to demonstrate that he has actually used a mark in commerce in order to apply for registration. However, the significance of the intent-to-use amendment has been limited by its omissions and ambiguous language. This groundbreaking amendment contains both a remedy hole and a bottomless pit of rights. Federal courts have the power to fill the hole by granting injunctive relief to applicants who can demonstrate that registration of their mark is imminent. Further, courts can seal the pit by construing the ambiguous language of the ITU amendment like its use-based counterpart. The full strength of the ITU provisions will be realized only after such judicial action.

216. Id.

217. Senator Hatch Response, supra note 190 , at 325-26.

218. Shalom Children's Wear, Inc. v. In-Wear A/S, 1993 TTAB LEXIS 16, at *10 (T.T.A.B. 1993).

219. See 15 U.S.C. \& 1052(d) (1994); Mother's Restaurants, Inc. v. Mother's Other Kitchen, Inc., 218 U.S.P.Q. 1046 (T.T.A.B. 1983). 